\title{
Capitalismo como religião: uma revisão teórica da relação entre religião e economia na modernidade
}

\author{
Capitalism as religion: a theoretical review \\ of the relationship between religion and economy in modernity
}

\author{
Allan da Silva Coelho* \\ Jung Mo Sung**
}

\begin{abstract}
Resumo
Walter Benjamin e um setor da Teologia da Libertação, em especial aquele que se articula em torno à Escola do $\mathrm{DEl}$, tem diversas convergências na crítica do capitalismo como religião. Esta proposição desafia pressupostos modernos das teorias da religião exigindo uma revisão conceitual que permita compreender melhor o poder de legitimação/fascínio ou questionamento da economia política capitalista. Neste artigo procuramos refletir sobre esta revisão da teoria da religião e propor uma abordagem que relaciona Benjamin e a teologia da libertação. Para isso, propomos exemplificar os desafios teórico-práticos desta relação e percorrer alguns estudos que re-situam os conflitos epistemológicos e políticos da religião com a modernidade. Em seguida, buscamos elementos de Benjamin e da Escola do DEI que fornecem instrumental analítico potente para a crítica do fetichismo capitalista como religião cotidiana. Por fim, sintetizamos a tarefa fundante de pensar, a partir da vida das vítimas, um necessário discernimento de deuses que permitem des-ocultar a razão mítico-teológica que caracteriza o espírito do fetiche.
\end{abstract}

Palavras-chave: capitalismo como religião; fetichismo; Escola do DEI; Walter Benjamin.

\begin{abstract}
Walter Benjamin and a sector of Liberation Theology, especially one that articulates around the DEl's School, has several convergences in the critique of capitalism as a religion. This proposition challenges modern assumptions of the theories of religion, requiring a conceptual revision that allows a better understanding of the power of legitimation/fascination or questioning of capitalist political economy. In this article we try to reflect on this revision of the theory of religion and propose an approach that relates Benjamin and the theology of liberation. For this, we propose to exemplify the theoreticalpractical challenges of this relation and to go through some studies that resituate the epistemological and political conflicts of the religion with the modernity. Next, we look for elements from the studies of Benjamin and the DEl's School that provide potent analytical tools for the critique of capitalist fetishism as a daily religion. Finally, we synthesize the fundamental task of thinking, from the life of the victims, a necessary discernment of gods that allow us to uncover the mythological-theological reason that characterizes the spirit of the fetish.
\end{abstract}

Keywords: capitalism as a religion; fetishism; DEl's School; Walter Benjamin.

Artigo submetido em 31 de maio de 2019 e aprovado em 16 de agosto de 2019.

* Doutor em Ciências da Religião pela UMESP. Professor da Universidade Metodista de Piracicaba. País de origem: Brasil. E-mail: allancre@yahoo.com.br

** Doutor em Ciências da Religião pela UMESP. Professor titular da UMESP. País de origem: Brasil. E-mail: jungmosung@uol.com.br 


\section{Introdução}

A crítica do "capitalismo como religião" tornou-se mais conhecida a partir da divulgação do fragmento de Walter Benjamin que veio a público em meados dos anos 1980. Tal associação não é exclusiva de Benjamin, uma vez que uma hipótese crítica com profundas semelhanças foi formulada desde os anos 1970 por um setor da Teologia da Libertação, mais notadamente aquele que se articulou em torno ao DEI, Departamento Ecuménico de Investigaciones (“Escola do DEI”1).

Michael Löwy, na introdução do livro “O capitalismo como religião”, propõe que este fragmento de Walter Benjamin é de uma atualidade impressionante e "tem curiosas semelhanças com a polêmica dos teólogos da libertação latino-americanos contra a "idolatria do mercado" (LÖWY, 2013b, p. 21). Em outro texto, Löwy já afirmara:

Seria interessante comparar "O capitalismo como religião" de Benjamin com os trabalhos de teólogos da libertação latino-americanos que, sem conhecer o excerto de 1921, desenvolveram, a partir dos anos 1980, uma crítica radical do capitalismo como religião idólatra. Assim, de acordo com Hugo Assmann, é na teologia implícita do próprio paradigma econômico e na prática devocionista fetichista cotidiana que se manifesta a "religião econômica' capitalista”. (LÖWY, 2007, p. 189-190).

De certa forma, este trabalho vem sendo realizado seja na comparação e análise das convergências e divergências entre setores da teologia da libertação e Benjamin, seja nos estudos que, inspirados neste arcabouço teórico, atualizam a radical crítica do sistema capitalista como expressão de uma religião dedicada a um falso deus, ídolo.

Entretanto, ainda é muito comum que se confronte, mesmo no âmbito das ciências sociais críticas, com o questionamento à possibilidade de associar o capitalismo e a religião. Em geral, o argumento de refutação da possibilidade evoca

\footnotetext{
${ }^{1}$ Grupo de pesquisadores que se referenciam nos estudos desenvolvidos no DEI, na Costa Rica, que inclui, entre outros, Hugo Assmann, Franz Hinkelammert, Pablo Richard e Jung Mo Sung.
} 
que o capitalismo é um sistema econômico autônomo, típico da Modernidade que tem como característica, entre outros, a racionalização, a secularização e a autonomia das diferentes esferas da vida. A associação entre capitalismo e religião não teria grandes contribuições seja por seus limites teóricos, seja pelo caráter regressivo da crítica, que resgataria relações pré-modernas para o estudo de problemas modernos.

O pressuposto sobre a Modernidade negaria importância tanto aos argumentos de Benjamin quanto aos do grupo identificado como Escola do DEI. Esta breve introdução explicita a problemática mais geral a partir da qual propomos pensar, entre as diversas abordagens e teorias da religião, que elementos são necessários para compreender a validade e a atualidade do conceito e análise do capitalismo como uma religião cotidiana do sistema econômico.

Assim como cada teoria da religião propõe-se a compreender o religioso em um determinado aspecto para entendê-la no conjunto das relações humanas, a associação "capitalismo como religião" permite a constituição de um vasto campo de estudos interdisciplinares em que as ciências da religião têm muito a contribuir. Visando colaborar na compreensão desta perspectiva crítica, propomos (a) alguns elementos que permitem afirmar a necessidade teórico-prática da abordagem "capitalismo como religião"; em seguida, à título de exemplo, (b) uma revisão pontual de teóricos das ciências humanas que colaboram na renovação da compreensão das relações entre modernidade e religião; e, por fim, (c) destacar certas características presentes tanto em Benjamin como na Escola do DEI que fornecem instrumental analítico potente de um abordagem teórica da religião para a crítica do fetichismo capitalista e o discernimento entre os deuses, que permite a crítica do mitos contemporâneos que legitimam a inversão ética do mal em bem. 


\section{Repensar a relação entre a religião e o capitalismo: uma necessidade teórico- prática}

Mesmo que parte das ciências sociais apoie-se no pressuposto da radical desvinculação entre capitalismo e religião, essa relação continua pertinente e atual como um desafio para a teoria da religião, presente nos debates públicos de forma implícita ou explícita, seja para criticar a ideologia vigente ou para legitimá-la.

Por exemplo, o filósofo Paulo Arantes, ao criticar o capitalismo atual, analisa a dimensão teológico-religiosa, em particular a escatológica, no questionamento da Modernidade percebendo uma alteração radical e mais profunda na relação entre o tempo e a política. Para ele, não se trata apenas de "mostrar que o futuro já foi consumido pelo endividamento universal que se exprime na supremacia devastadora do capital fictício" (ARANTES, 2014, p. 77), mas voltar a reconhecer na política sua dimensão de foco gerador de expectativas humanas. Arantes defende o elo entre a compreensão teológica e escatológica e suas consequências sociais, ambientais e políticas.

Por outro lado, também encontramos em quem defende o neoliberalismo, relações teológicas e religiosas associadas à vida econômica-política, como nas ações de enfrentamento da crise econômica atual conhecidas como "Políticas de Austeridade". Por exemplo, no início desta crise, o então presidente do governo espanhol, Mariano Rajoy, afirmou que “o esforço não será inútil. As nuvens cinzas desaparecerão, nós elevaremos a cabeça e veremos o dia onde falaremos bem da Espanha; o dia onde nós olharemos a frente e onde nós não nos lembraremos mais dos sacrifícios” (LE MONDE, 2012). Para o sociólogo Frédéric Lebaron, o aspecto sacrificial "de ordem da ética quanto da racionalidade, suscita por parte de numerosos comentadores uma espécie de júbilo mórbido, como se o sofrimento do povo tivesse também uma dimensão "purificadora" (LEBARON, 2011). Em sentido semelhante, resgatando aspectos da tese de Weber, Alain Frachon (2011) propõe a afinidade entre a cultura protestante na Alemanha e o tipo de medidas propostas para a saída da crise. Ele defende que muitas análises políticas se equivocam por 
desconsiderar a dimensão religiosa, como o sentido do pecado que permeia as medidas ascéticas de toda a Política de Austeridade.

Para Slavoj Zizek (2010), a crise reforça o caráter de sua naturalização, em que medidas regulatórias de austeridade são propostas como se fossem lógicas financeiras neutras, abstraídas de decisões éticas e políticas. Mas, ao mesmo tempo em que estabilizam a economia, afetam os setores já fragilizados da sociedade, como os pensionistas, imigrantes e trabalhadores precarizados. Agrava-se um contexto de desigualdades em escolhas que penalizam amplos setores da sociedade. Mas, neste contexto, em que força se apoia a coesão deste sistema capitalista que, em crise, mantém forte adesão? A força mobilizadora que fascina as pessoas para sua adesão ao modo de vida capitalista é o poder de sedução da mercadoria, pelo consumo, no direcionamento de símbolos que gestam modelos de desejo e expectativas de realização humana². Este mecanismo, tacitamente aceito, gesta apostas e organiza sentidos, não exclusivamente do âmbito da razão analítica. Há aquilo que Hinkelammert (2008) chamou de razão mítica, cujo papel e o tipo de discernimento necessário para compreendê-la precisa ser aprofundado, como contribuição de um tipo de teoria da religião.

Severino Croatto, em um dos livros coletivos de referência do DEI, afirmou:

A Bíblia registra a luta entre o Deus de Israel, Iahweh, e os deuses estrangeiros (élohê, 'deuses estrangeiros) ou simplesmente outros deuses (élohim, ajerim). Os deuses são um símbolo, altamente operativo, da força política de um povo. Pode-se afirmar então que todos os deuses estão em luta, como projeção dos conflitos de poder político-social entre os grupos ou povos. [...] os deuses, como símbolos de uma totalidade de sentido, estão em luta entre si. [...] A luta entre os deuses é uma expressão universal do conflito de poderes cuja instância natural e mais evidente é política. E, nisso, nem a Bíblia nem Israel podem ser originais (CROATTO, 1982, p. 39-40).

Curiosamente o Papa Francisco, que é uma das poucas vozes com expressão mundial a denunciar o sistema econômico entre as ameaças atuais para a vida dos pobres, incluiu em seu magistério o tema da idolatria, do fundamentalismo

\footnotetext{
${ }_{2}^{2}$ Para aprofundar o argumento, ver Assmann; Hinkelammert (1989), Sung (1998), Coelho (2014).
} 
econômico e a necessidade da superação do sistema capitalista, mesmo sem incorporar a crítica do sistema como religião. Entretanto, expressa um protesto em nome do Deus dos pobres. É uma expressão daquilo que Max Weber chamou de guerra ou luta dos deuses.

Em especial na América Latina, este conflito já era tema dos debates do DEI no final dos anos 1970, quando na apresentação do livro coletivo em que Pablo Richard diz em nome da equipe:

Na América Latina de hoje, o problema central não é a questão do ateísmo, o problema ontológico da existência ou não de Deus. Ser ou não ser, não é essa a questão. A discussão não se dá no âmbito metafísico que tradicionalmente o caracterizava, o âmbito ontológico, universal e abstrato. E também não versa sobre o problema do ateísmo, ligado ao secularismo e à crise da própria modernidade ocidental europeia (RICHARD, 1982, p. 07).

Apesar de ainda não criticar explicitamente a compreensão do que é a modernidade e o lugar da religião, a Escola do DEI distingue a modernidade ocidental europeia da realidade social latino-americana e o papel e o lugar da religião e teologia nessa. Por isso, afirma que o problema central não é a relação fé versus falta de fé/ateísmo, mas "na idolatria como culto aos falsos deuses do sistema de opressão" uma vez que "todo sistema de opressão caracteriza-se precisamente por criar deuses e gerar ídolos sacralizadores da opressão e antivida” (RICHARD, 1982, p. 07).

A última frase em nada é contraditória com a afirmação de Max Weber sobre a continuidade do oferecimento de sacrifícios a deuses no mundo moderno. É claro que a afirmação da Escola do DEI é mais incisiva na ligação que faz entre sacrifícios e sistemas sociais opressivos e não pretende se manter em uma postura de "neutralidade ética" da epistemologia das ciências sociais proposto por Weber e outros. Weber reconhece a existência de lutas entre os deuses, mas afirma que, enquanto cientista, não se pode fazer juízo sobre esses deuses, nem discernir qual 
deles é o melhor (WEBER, 2001b). Esta é uma das questões fundamentais em que é preciso avançar.

A crítica aos sistemas sociais que exigem sacrifícios a seus deuses como sistemas de opressão não é meramente resultado do fato de ser uma reflexão teológica. Pois, como diz a citação acima, boa parte da teologia europeia e as outras que seguem a mesma linha de raciocínio pensam que os desafios centrais da teologia seriam o ateísmo, o problema ontológico da existência de Deus e, mais recentemente, a interpretação das doutrinas da fé em termos da linguagem e cultura moderna e pós-moderna. Isto é, aceitam a tese "tradicional" de que as sociedades modernas são secularizadas e que a religião é ou deve estar reduzida à esfera do privado e do fundamento último do sentido existencial da vida atual e a pós-morte. Essa nova crítica é produto de uma articulação diferente, original, entre a reflexão teológica na perspectiva da libertação, uma visão crítica da modernidade e do lugar e papel das religiões nela, e uma crítica da epistemologia das ciências. Tal crítica às ciências sociais modernas não é somente em termos da sua pretensão da neutralidade ética, mas também da noção de racionalidade e da sua relação com a utopia e os mitos.

Nesta reflexão, pretendemos contribuir com a caracterização do tipo de teoria sobre a religião que permite compreender a dinâmica do capitalismo como religião e colaborar no discernimento dos deuses em vista da afirmação da dignidade humana para negar a legitimidade de quem, de forma violenta, cínica e cruel propõe a morte de alguns como bem para outros. Parece que a noção de discernimento de deuses permite pensar um tipo de teologia ou de teoria da religião que, em diálogo com as ciências sociais, potencialize a crítica e superação de uma lógica sacrificial, sem a qual o sistema capitalista apresenta-se como autorreferenciado. Entretanto, para pensar isso é necessário resgatar o contexto histórico-político em que se consolidam os conflitos entre o pensamento racional moderno e a dimensão religiosa da vida. 


\section{Modernidade e Religião: conflitos teóricos e políticos}

Uma linha de estudos sobre estes conflitos trabalha com a ideia de que o paradigma da secularização, longe de constituir uma teoria, fundamenta-se como decorrência de disputas históricas. Desse processo, teria se formado a ideia da clara distinção entre economia e religião. O sociólogo Sébastien Tank-Storper afirma que na fórmula básica do pensamento moderno a relação entre a Modernidade e a religião parece ser uma aliança de campos semânticos contrários. Disso, deveríamos concluir como contraditória qualquer proposta de relacionar dois conceitos que se excluem mutuamente, como a economia e a religião. O próprio Tank-Storper diz que:

A análise das relações entre religião e modernidade tem sido dominadas há tempos pela ideia de uma relação de exclusão entre as duas noções. Mesmo se algum dos principais fundadores das ciências sociais não produziram realmente teoria sistemática do fim da religião, todos desenvolveram, em um nível mais ou menos explícito, a ideia de uma oposição entre a modernidade e o universo tradicional da religião (TANKSTORPER, 2010, p. 742).

Desse modo, mesmo que não haja uma teoria clássica que estabeleça a necessidade empírica desta mútua exclusão conceitual, diversas teorias da religião estão fortemente marcadas por esta compreensão de oposição. A título de exemplo, Tank-Storper indica que em Durkheim a diferenciação institucional é uma das características típicas do processo de modernização. Em Weber, a Modernidade se caracteriza pela difusão da racionalidade que leva superação e perda de credibilidade das formas de pensar e de agir religiosamente.

Não apenas teóricos considerados clássicos apontam esta tendência. Bryan Wilson caracterizava a Modernidade pelo triplo processo que inclui a racionalização das representações e das práticas, a afirmação crescente da autonomia individual e a diferenciação funcional da sociedade. Assim, de acordo com Wilson (1982), as instituições, as práticas e a consciência religiosas perderiam seu espaço social. A sociedade moderna se caracterizaria pela irrelevância das instituições religiosas e seus símbolos. 
Na mesma perspectiva de conclusão de Tank-Storper está a pesquisa de Olivier Tschannen (1992), para quem desde os clássicos das ciências sociais até os novos pesquisadores estariam influenciados por um paradigma de compreensão que pressupõe a oposição radical entre as esferas modernas da vida e a religião. Nos marcos deste paradigma, a pergunta se o capitalismo pode ser compreendido como religião recebe uma resposta simples e considerada definitiva: no quadro teórico da Modernidade, o capitalismo é um sistema econômico autônomo e secular, portanto não relacionado com religião. Assim, problematizar essa relação nos marcos categoriais que os compreende como excludentes e opostos tornaria a reflexão limitada e fadada a um contrassenso.

No processo de desenvolvimento da Modernidade, passando pelo Iluminismo e em especial no Positivismo, consolida-se um tipo de compreensão racional da vida que se propõe superar em um processo evolutivo de desenvolvimento todo e qualquer aspecto da mentalidade religiosa e mítica considerada resquício de uma forma de viver já superada. Desse modo, todo tipo de pensamento que articula linguagem religiosa ou uma dimensão teológica teria sua relevância limitada à vida privada e às opções pessoais, de pessoas que "ainda" consideram tal dimensão. A Modernidade que, segundo Robert Legros (1990), se concebe como um "arrancamento" às tradições e à religião é a mesma que se propõe, como diz Alphonse Dupront, através da razão a "construir sozinha seu próprio universo" (DUPRONT, 1996, p. 19).

A expressão "arrancamento" é significativa pois indica uma mudança tempestiva sobre algo que parecia sólido, enraizado, como fundamento não visível. Para o mundo anterior à Modernidade, essa raiz é a religião. É uma visão coerente com um desenvolvimento histórico de confronto e disputas sociais. No primeiro momento, na superação do feudalismo pela modernidade capitalista, o Racionalismo enfrentou a tradição Escolástica e seus pressupostos científicos de autoridade. No segundo momento, a Filosofia das Luzes enfrentou a tutela das instituições, em especial a eclesial, na exigência da autonomia de pensamento e pelo desejo de atingir a maioridade racional. Depois, o Positivismo amplia o 
confronto social que não se restringe mais à filosofia escolástica nem ao papel da instituição eclesial, mas a todo o pensamento religioso e à própria religião.

Tal é o processo em que a expressão "capitalismo como religião" parece anacrônica aos olhos de setores das ciências sociais. Para Jean-Paul Willaime, as ciências sociais, "enquanto vontade de analisar a sociedade e sua evolução" (1995, p. 87), teriam surgido das mudanças sociais que provocaram também o surgimento da sociedade moderna. O questionamento sobre o futuro do religioso na Modernidade seria inerente e constitutivo da metodologia da sociologia e das ciências sociais modernas. A origem interna das ciências sociais associada ao surgimento da Modernidade situa seu quadro de categorias de referências no âmbito, claro, do pensamento moderno. Neste sentido, em geral, quando as ciências sociais modernas investigam o "futuro do religioso" (expressão de Willaime) aplicam um princípio básico (considerado indubitável) de que "quanto mais a Modernidade avança mais a religião se retira, até recolher-se na esfera privada, nos confins da vida social” (BOBINEAU; TANK-STORPER, 2011, p. 13). No entanto, as ideias de racionalização e de secularização constituiriam muito mais um paradigma do que uma teoria articulada.

Entretanto, se a tensão entre as ciências sociais e a religião pode ser compreendida na perspectiva de sua constituição, também pode ser analisada no âmbito de sua finalidade. A socióloga Danièle Hervieu-Léger afirma que, na Modernidade, a dimensão mítico-religiosa foi entendida mesmo como obstáculo ao processo de racionalização, sendo tarefa do pensamento crítico eliminar os falsos saberes mágicos e/ou teológicos. Ainda, as ciências sociais supõem um projeto unificador na busca de leis e regularidades do mundo social frente o aparente caos da realidade. A religião também expressaria uma visão unificante da realidade, com a ambição, enquanto sistema de significações, de "conceder um sentido total ao mundo e de recapitular a multiplicidade infinita das experiências humanas" (HERVIEU-LÉGER, 2008, p. 23). Ambas, a partir de fundamentos diferentes, expressariam a mesma aspiração humana de explicar a vida humana. 
Teríamos um conflito de tipo político-epistemológico, entre interpretação científica e teológico-religiosa, que, apesar de historicamente parecer insuperável, não o seria. Hervieu-Léger destaca que no século XVII esse conflito não existia. Mais do que isto, no início da revolução científica (com Newton, Descartes, Pascal e outros) não se pensava que um ateu pudesse ser geômetra. A mudança da perspectiva, entre outros fatores, considera o enfrentamento da Igreja Católica, pela manutenção de seu poder social, com os cientistas, empenhados na autonomia da produção do saber.

Na tensão com a instituição eclesial decorreria a formação de um senso comum da comunidade científica que caracteriza negativamente a religião e a teologia, que hoje permanece totalmente implícito. A necessidade de eliminar a religião para libertar o espaço de produção de uma interpretação científica do social (da natureza, da história, do psiquismo humano) só raramente é formulada como um imperativo explícito da prática da ciência, em geral, e da prática das ciências humanas, em particular.

Entretanto, para Tank-Storper, mesmo que a oposição entre religião e modernidade seja largamente fictícia, imaginária, não impede que tenha um papel na compreensão das tensões e contradições internas do religioso (TANKSTORPER, 2010, p. 749). De fato, a pluralidade de perspectivas permite as mais variadas formulações e contribuições específicas sobre os problemas da sociedade atual. Por isso, Hervieu-Léger indica que, se certo campo científico se constitui a partir da premissa da incompatibilidade, o trabalho coletivo de pesquisa indica a necessidade de aprofundar certas abordagens teóricas da religião.

\section{Modernidade e barbárie: brilho sedutor e exploração}

Entre as abordagens diferentes, destacamos a teoria que considera que o capitalismo pode e deve ser criticado como uma religião. Sua singularidade teórica advém justamente da articulação entre a análise das condições concretas da vida sob o sistema (a base econômica da exploração) e as formas de significação e 
legitimação mítico-teológica, enquanto espírito que move e submete as pessoas à exploração. No mundo moderno, o espírito que mobiliza e propõe sentido à ação humana se expressaria não mais nas tradicionais instituições religiosas, mas no próprio capitalismo. Seria paradoxalmente a dimensão religiosa de um sistema econômico racional e desencantado que nega a necessidade de qualquer motivação religiosa enquanto a recria.

Em Weber, a religião é fator externo que legitima a implantação do capitalismo pela afinidade eletiva com seu espírito. Sua conclusão é que, depois de consolidado, a dimensão religiosa seria dispensável e desnecessária. Benjamin e os teóricos da Escola do DEI entendem o argumento de forma diferente, pois o discurso religioso não seria mais exterior e dispensável uma vez que estaria nos fundamentos do sistema, no fetichismo. Desse modo, a religião do capitalismo surge da contradição real da vida neste sistema. Se a religião oferece razões para viver, morrer e matar, como um modo de crer que instaura horizontes de compreensão da vida e do que ainda-não-é, a “crítica da religião” permanece, como disse Marx, a crítica primeira.

Enfim, a própria estrutura da Modernidade, como esperança de realização, cria, associada à racionalização progressiva que abole as religiões tradicionais enquanto sistemas de significações e motor dos esforços humanos, uma estrutura afim à religião, uma utopia que ilumina e seduz pela sua promessa de futuro. A revisão das categorias da razão, na perspectiva da ampliação da compreensão da racionalidade humana, apoiada em diferentes correntes divergentes da exclusividade da razão instrumental, permitiu ampliar os horizontes de plausibilidades racionais ao buscar racionalidades abrangentes que não excluam por opção ideológica as categorias míticas. Em diferentes perspectivas podemos pensar a "permanência" da religião de forma difusa, implícita e invisível em diversas esferas da chamada "vida profana" (consideradas não religiosas), como a economia (HERVIEU-LÉGER, 2008). 
Benjamin e os teólogos da libertação contribuem com uma dessas possibilidades. No entanto, quando Benjamin afirma o capitalismo como religião, diz que a dimensão da vida referente aos aspectos econômicos assumiu o lugar considerado próprio da esfera religiosa, mas não só como substituição de "sistemas de sentido”, mas na apropriação das lógicas típicas dos mitos e da teologia judaicocristã. O conceito que provoca a crítica do capitalismo como religião é o de fetiche da mercadoria e a expectativa é insurgir-se contra a normalidade da vida cotidiana imposto pelo espírito do fetiche.

No capitalismo, a mercadoria disciplina a vida na sociedade globalizada em suas relações de produção, mas também de consumo. Impõe um padrão de normalidade no consumo que não se reduz à operação mercantil da compra e venda, mas institui uma forma de viver (SUNG, 1998). Não se trata de pura razão instrumental, mas de uma racionalidade que convence e gera apostas existenciais. A lógica do consumo e da ostentação de mercadorias proporciona a distinção social, o "reconhecimento" do outro pela posse e, também, autoestima. Pela aquisição de bens, o ser humano deseja superar sua condição atual e realizar-se plenamente. O consumo oferece felicidade plena na superação dos limites da vida humana. Desse modo, as relações de consumo não são apenas relação econômica, mas possuem uma dimensão espiritual. É uma dimensão simbólico-religiosa que assegura o aspecto fascinante do sistema (SUNG, 2005). Teríamos um funcionamento que questiona o pressuposto de auto compreensão moderna de seu carácter antirreligioso. Seria um resultado do próprio fetichismo da mercadoria, que não é um simples bem/coisa, mas articula aspirações, sucesso, felicidade e outros valores que concedem ao seu consumo um aspecto transcendente, fascinante, espiritual. No entanto, esta mesma mercadoria é a expressão concreta do caráter violento do sistema produtivo, seja pela objetivação do trabalho, seja a exploração econômica de seu verdadeiro valor (custo), na relação de exploração do centro sobre a periferia e do capital sobre a natureza. 
O consumo da mercadoria, em sua dimensão fascinante, oculta a sua dimensão violenta, por vezes associada à dimensão do simulacro como logo ou imagem33. Se o desespero é sensação generalizada, a violência e morte contra aqueles que não realizam o ideal do consumo são vistas como uma violência legítima, exemplar, necessária (COELHO, 2014). Fascinados pelo feitiço do consumo, essa exploração, exclusão ou morte são consideradas como justas, legítimas e, ainda, como progresso e científico. São "sacrifícios necessários”, sempre considerados metáforas do funcionamento do sistema capitalista. O capitalismo neoliberal globalizado leva ao extremo suas teses, reforçando sua religiosidade e sua teologia endógena.

O discurso de austeridade é mais que figurativo, propondo sacrifícios expiatórios em vista de um futuro melhor. Rigor, austeridade, esforços, sacrifícios, disciplinas, medidas doloridas estão associados às promessas de futuro, em que a expiação conduz à redenção. Uma lógica de sacrifício racionalizada de modo "laico e secular"? Ou o espírito do capitalismo produz uma aposta de fé que o legitima e, ao mesmo tempo, é onipresente e invisível?

As contradições do sistema são evidentes, como a sedução do consumo, da tecnologia, das promessas do progresso continua a gerar adesão de muita gente que teria motivos para rebelião: com a exclusão, a opressão, a exploração, a repressão, com as mortes de cada dia, com a crise social, econômica e ambiental, o capitalismo permanece ampliando seu mercado mundo afora. A diversidade de vítimas (trabalhadores, desempregados, excluídos e oprimidos por raça, gênero, geração, sexualidade, cultura...) parece não abalar a confiança no futuro promissor que advém do mercado capitalista. Esta crítica do capitalismo como religião contribui na medida em que colabora no processo compreender o fetichismo presente na vida cotidiana e a elaboração de uma potente critica teológica em uma reflexão de discernimento de deuses.

\footnotetext{
${ }^{3} \mathrm{~A}$ interessante relação entre fetichismo e estética pode ser aprofundada em Moreira (2015).
} 


\section{Questões sobre a religião da vida cotidiana}

A afirmação de que o capitalismo é religião permite modificar radicalmente a compreensão do mundo moderno. Ele não é mais visto como secularizado e ateu, mas com um tipo de idolatria. O conceito de idolatria provém da Bíblia, especialmente dos profetas que criticavam o sistema religioso-social do seu tempo. Com o passar do tempo, a noção de idolatria no cristianismo ficou reduzida à crítica à adoração de ídolos nas religiões pagãs e, também, no interior do próprio cristianismo. Retomando a noção bíblica original, a "Escola do Dei” produziu um conjunto importante de obras teológicas e de crítica social.

Com a publicação em 1985 do fragmento de Walter Benjamin ampliou-se a área de interesse dos que veem no capitalismo uma "religião da vida cotidiana". Benjamin inicia o seu fragmento "Capitalismo como religião" dizendo:

O capitalismo deve ser visto como uma religião, isto é, o capitalismo está essencialmente a serviço da resolução das mesmas preocupações, aflições e inquietações a que outrora as assim chamadas religiões quiseram oferecer resposta. A demonstração da estrutura religiosa do capitalismo, que não é só uma formação condicionada pela religião, como pensou Weber, mas um fenômeno essencialmente religioso nos levaria ainda hoje a desviar para uma polêmica generalizada e desmedida (BENJAMIN, 2013, p. 21).

Nesta afirmação, podemos encontrar pelo menos três teses bastante provocativas. A primeira, e com certeza a central, é a afirmação de que o capitalismo não é um sistema social secularizado, mas é ou funciona como uma religião. Essa tese rompe com a visão tradicional do mundo moderno e do capitalismo como livres da religião. Além disso, para que se possa ver o capitalismo como uma religião é preciso repensar o seu conceito moderno comumente utilizado no estudo do que se chama de "campo religioso" ou do "fenômeno religioso", uma vez que não permite a associação entre o campo econômico e o campo religioso. Por mais que estudiosos do campo religioso utilizem conceitos ou teorias advindas da economia para estudar as religiões ou grupos religiosos (por exemplo, o uso de teoria de escolhas racionais na sociologia da religião ou a noção de "mercado religioso”), tem-se muita dificuldade em admitir no capitalismo uma religião, como 
vimos, em grande parte pelo recorrente caracterização do mundo moderno na relação binaria entre o religioso e o secular.

A segunda tese aparece na justificativa dada por Benjamin para ver no capitalismo uma religião. Ele diz que "o capitalismo está essencialmente a serviço da resolução das mesmas preocupações, aflições e inquietações a que outrora as assim chamadas religiões quiseram oferecer resposta.” Nessa afirmação podemos ver dois tipos de religiões: (a) as religiões de hoje, que não respondem mais ou que têm suas respostas não mais aceitas para questões que (b) as religiões do passado costumavam resolver. Isto é, no passado, as religiões resolviam as grandes questões da vida social, que na verdade incluía a totalidade das questões sociais e políticas. As religiões modernas não conseguem mais cumprir essa função por conta da distinção entre a religião e o secular, que passou a ser uma relação de contradição na medida em que a religião foi reduzida à esfera do privado, às preocupações com a "vida pós-morte".

Benjamin, ao afirmar que o capitalismo é uma religião, assume a noção não moderna de religião para caracterizar o capitalismo. Nesse sentido, ele antecipa a atual discussão sobre a "invenção da religião" no mundo moderno. Estudiosos da religião influenciados especialmente pela teoria pós-colonial, como por exemplo Talal Asad (1993, 2003), Tomoko Masuzawa (2012), Brent Nongbri (2013), D. Dubuisson (1998), mostram que essa noção de religião reduzida a esfera do privado é uma "invenção" ou construção do Ocidente para, em grande parte, solucionar os problemas advindos das guerras de religiões e o processo de modernização com o advento do capitalismo.

Nas sociedades antigas não havia um conceito de religião. Isso fica mais claro se levarmos em consideração que para que possa definir o "ser religioso" é preciso que haja a noção de um ser não religioso, dicotomia que não existia no mundo antigo. O exemplo do que ocorreu no Japão no século XIX pode nos ajudar perceber a profundidade e implicações dessas novas pesquisas. Jason Ananda Josephson (2012) argumenta que não havia no Japão uma palavra que 
correspondesse ao que hoje nomeamos como religião. Isso se tornou um problema quando os norte-americanos forçaram o governo japonês a assinarem um tratado, em 1853, em que incluía uma cláusula de liberdade religiosa no país. Como a língua japonesa não tinha uma palavra correspondente para religião, o tradutor teve que criar um neologismo, Shukyo, que literalmente significa "ensinamento de uma seita”.

Não é nosso objetivo aprofundar essa questão da criação de uma nova palavra para dar conta do que o mundo moderno Ocidental chama de religião, nem das razões e implicações de se utilizar o termo "religião" para traduzir palavras que nos textos religiosos antigos, por ex. threskeia, no Novo Testamento, não tinha a mesma conotação moderna. O que queremos apontar aqui é que o que nós hoje entendemos por religião, algo distinto do secular e, como diz Karen Amstrong (2000), sem relação com as lutas de poder político, não pode ser visto como um conceito universal e aplicado para sociedades antigas e para culturas não Ocidentais do nosso tempo que ainda não foram totalmente "reformatados" pela expansão da cultura ocidental e da globalização capitalista.

A terceira tese presente na citação do texto de Benjamin é a de que a teoria weberiana do papel da religião, em particular do cristianismo calvinista, na formação do espírito do capitalismo não é suficiente para compreender a gênese e a estrutura do capitalismo. Mais do que condicionado pela religião, para Benjamin, o capitalismo tem uma estrutura religiosa. Ele próprio reconhece que está adentrado em uma discussão que geraria muita polêmica. Não somente no tempo dele, mas ainda hoje se levarmos em consideração o que argumentamos acima.

Mesmo sem aprofundar aqui essa discussão, podemos citar um texto de Weber que não é muito citado no estudo das religiões, mas nos oferece uma pista realmente interessante para a nossa discussão. Ao analisar a "ciência como uma vocação" e "as lutas de deuses” que ocorrem nas sociedades, Weber diz: 
Desconheço como se poderia encontrar fundamento para decidir "cientificamente" a questão do valor da cultura francesa comparada à alemã. Também aí diferentes deuses se combatem e, por certo, infinitamente. Por conseguinte, tudo se passa exatamente como se passava no mundo antigo, que se encontrava sob o encanto dos deuses e demônios, conquanto assuma diferente sentido. Ofereciam sacrifícios a Afrodite os gregos, depois a Apolo e, acima de tudo, a cada um dos deuses da cidade. Continuamos a proceder de maneira semelhante, conquanto nosso comportamento haja rompido o encanto e se haja despojado do mito que ainda vive em nós. (WEBER, 2001a, p. 48).

Weber diz que, no fundo, não há grande diferença entre o mundo antigo e o moderno: continuamos oferecendo sacrifício aos deuses. Só que agora assume um sentido diferente. Antes era para deuses pessoais, porque o mundo era encantado; hoje, em um mundo desencantado, os sacrifícios são oferecidos a forças impessoais, às leis do sistema de mercado. Por isso ele diz: "Atualmente, a religião tornou-se 'rotina do dia-a-dia'. Os deuses antigos abandonaram suas tumbas e, sob a forma de poderes impessoais, porque desencantados, esforçam-se por ganhar poder sobre nossas vidas, reiniciando suas lutas eternas" (WEBER, 2001b, p. 49).

Há outra diferença que tem a ver com o fato de um mundo ser encantado ou desencantado: em um mundo encantado, com deuses pessoais, cabe à religião oferecer esses sacrifícios e manter o bom funcionamento do sistema social; em um mundo desencantado como o nosso, diante de deuses que se manifestam como forças impessoais, os sacrifícios não são mais ofertados pelas religiões tradicionais, mas - podemos deduzir - pelo próprio sistema capitalista. Por isso, a religião que realmente conta na sociedade não é mais vivida nos dias santos e festivos, mas como "rotina do dia a dia". Dessa forma, a oferta de sacrifícios aos deuses não mudou entre o mundo Antigo e o Moderno, mas adquiriu um novo sentido. Nesse sentido, podemos ver uma possível relação entre essa tese de Weber e a de Benjamin. 


\section{Capitalismo como religião e o discernimento de deuses}

A articulação e aprofundamento dessas duas últimas teses - a noção de religião a partir do binômio religião/secular como uma invenção da modernidade Ocidental e a continuidade e transformação dos oferecimentos de sacrifícios aos deuses - nos permite ver como plausível a principal tese na citação de Benjamin: capitalismo é uma religião. Mas, não é comum vermos estudiosos da religião, das mais diversas áreas de conhecimento, fazerem esse tipo de pesquisa ou até mesmo levar a sério a possibilidade de que o capitalismo possa ser ou funcionar como religião. Em parte porque essa perspectiva obriga a rever alguns dos pontos chaves das ciências sociais e humanas modernas que estudam a religião: a própria noção de religião, a separação entre o secular e o religioso e o foco do estudo das ciências da religião somente no campo religioso (estruturas de mitos e ritos, instituições e experiências religiosas).

Franz Hinkelammert concorda fundamentalmente com a intuição de Benjamin, mas diz que ele se equivoca em caracterizar o capitalismo como religião sem dogma e sem teologia. Haveria na fundamentação das ciências burguesas uma relação de causalidade essencialmente mítica, desenvolvida em derivação dos mitos da ortodoxia cristã. Por isso mesmo, "as ciências empíricas são a teologia da modernidade, portanto, também a teologia do capitalismo” (HINKELAMMERT, 2008, p. 167). Essa teologia não pode deixar de ser concebida, pois a transcendência agora está no interior da realidade como empiria. Supõe conceitos mobilizadores e validantes do sistema capitalista como a vida sem morte e um ser onisciente e onipotente. Para Hinkelammert, "a ciência empírica é tão religiosa como o capitalismo. É parte da religião da modernidade que se exerce como culto" (2008, p. 173).

Hinkelammert avança sua hipótese ao indicar que a Modernidade seculariza a linguagem mítica, mas não a supera. Deste modo, oculta a sua dinâmica religiosa, sua fé fundamental, esconde uma estrutura epistemológica teológica e a mentalidade de exigências sacrificiais. Se a força do sistema capitalista vem deste 
seu "espírito" com fundamentação mítica, é preciso desvelá-lo, retirar as condições que asseguram o seu ocultamento, iluminando com a razão a dinâmica dos mitos. Esta é a crítica da razão mítica, que deve estender seu potencial analítico e de desencantamento também aos fundamentos da secularização ilustrada.

Para isto, é necessário superar a oposição moderna entre razão e mito, identificando o papel da razão mítica no funcionamento da racionalidade humana como tal. Se o paradigma moderno não é capaz de compreender a racionalidade humana em sua complexidade precisa ser modificado. A crítica fundamental e radical, portanto, não é afirmar que o "Capitalismo é Religião" (esta afirmação é radical apenas no âmbito de uma epistemologia moderna que distingue radicalmente as esferas da vida e os limites da razão humana), mas a sua denúncia como uma "religião do fetiche" (HINKELAMMERT, 1983), isto é, uma religião de aspecto sacrificial. Esta racionalização sacrificial, ou a "religião idolátrica", permite que o mal (exclusão e morte) seja compreendido de forma positiva, necessária, gerando boa consciência a quem o produz ou aceita coniventemente.

Se o capitalismo como religião é uma construção humana e funciona em uma lógica sacrificial que mata os próprios seres humanos, existe um algo de perverso, invertido. Em outras palavras, afirmar o capitalismo como religião não se trata de indicar, de modo neutro e evidente, uma dimensão espiritual e teológica, mas de desvelar um mecanismo oculto, mítico, que reproduz o circuito sacrificial religioso. A espiritualidade que permite uma boa consciência frente à morte dos seres humanos e a destruição do mundo, sem aceitar nenhuma mudança, tem sua teologia. Quando se mata o ser humano e destrói o mundo acreditando que se faz um serviço à humanidade, é preciso um critério de julgamento desta teologia como idolatria.

Uma teoria da religião que enfrente este debate colabora com a tradição crítica que, ao reconhecer o combate entre os deuses, em geral uma luta entre os deuses da opressão, desempenha a tarefa de reflexão engajada de discernimento entre os deuses. A crítica dos mitos fundantes e da teologia subjacente é possível a 
partir de elementos claros de julgamento, que se constituem como referenciais absolutos no lugar dos ídolos-fetiche. Este critério, na Escola do DEI, é a vida da vítima, enquanto em Walter Benjamin é o ponto de vista dos vencidos à espera de redenção.

Danièlle Hervieu-Léger, quando analisa os processos de permanência e reprodução do religioso na vida cotidiana secular, afirma que é preciso analisar o “enraizamento religioso que lhe é específico" (2010, p. 1155). Este enraizamento produz modelo de interpretação e gera matrizes que possuem referências transcendentais sutilmente ocultas, invisíveis, pois são conexões tão próximas que funcionam mesmo que não se perceba. Parece-nos que isso se aplica ao capitalismo, que sem parecer uma religião "aparece como $o$ horizonte de percepção da realidade, critério de julgamento da própria existência” (MOREIRA, 2012, p. 37). Desse modo, torna-se o único horizonte de compreensão da vida.

A afirmação de outro Deus, que se identifica com a vítima, nega a legitimidade religiosa do sistema e oferece outro parâmetro de julgamento. Essa crítica do horizonte de compreensão como totalidade incondicionada está presente na Escola do DEI desde seu início. Enrique Dussel, por exemplo, reivindica a vítima como critério de discernimento frente a idolatria-fetiche como necessidade frente “o projeto de um sistema assim fetichizado como perverso enquanto tal (...) [em que] a crítica da religião (do dominador) é o começo de toda crítica” (DUSSEL, 1980a, p. 101). O mesmo aforisma de Marx recebe agora outro potencial críticoanalítico.

\section{Considerações finais}

Se por um lado, boa parte do pensamento crítico das ciências humanas modernas se compreende como adversa ao religioso, por outro, também há setores deste mesmo pensamento crítico que questionam esta lógica característica da Modernidade. O questionamento deste pressuposto inicia-se não no âmbito das teorias analíticas, mas na sensibilidade frente às vítimas que o sistema capitalista 
produz ao impor-se como única forma humana de existir. Consta-se que o capitalismo produz sistematicamente dominação, exploração, exclusão social e mata muita gente em sua dinâmica de funcionamento. Mas esta situação nem sempre transforma insatisfação em rompimento com a legitimidade do capitalismo, expressando em muitos casos o desejo de participação plena no sistema.

Mesmo frente aos dados da realidade que demonstram a crueldade social do Capitalismo, o terror da violência e o horror frente às suas vítimas não diminuem a força e legitimidade do sistema, que continua a produzir fascínio e adesão. São duas faces que, opostas, se articulam unidas. É uma expressão da ambiguidade na qual a violência e exclusão estão relacionadas a um irresistível fascínio que mantém o desejo de participar, uma adesão que o reforça. A força mobilizadora que fascina as pessoas para sua adesão ao modo de vida capitalista estaria relacionada com o poder de sedução da mercadoria, pelo consumo. Fetichismo e idolatria são potentes categorias de compreensão desta relação.

Como argumentamos, as ciências sociais realizam um importante trabalho de revisão das relações entre religião e Modernidade, em especial identificando os seus conflitos políticos e epistemológicos, que permite avançar nos estudos da dimensão mítico-religiosa do capitalismo. A tarefa desta critica parece cada vez mais urgente frente ao acirramento mundial do fundamentalismo econômico e do culto permanente da morte dos pobres como sacrifício necessário para um bem maior. Trata-se de trabalho coletivo que convida ao aprofundamento teórico.

Benjamin indicou que a teologia é o espírito sem o qual não se vence. É fundamental que um tipo de pensamento teológico se dedique à radical crítica dos mitos que legitimam a inversão ética do mal em bem, colaborando para que os estudos de religião sejam decisivos na disputa entre a possibilidade da vida de todos e a realidade de morte que se generaliza. 


\section{REFERÊNCIAS}

AMSTRONG, K. Islam: short history. New York: Modern Library, 2000.

ARANTES, P. E. O novo tempo do mundo: e outros estudos sobre a era da emergência. São Paulo: Boitempo, 2014.

ASAD, T. Formations of the Secular: Christianity, Islam, Modernity. Stanford:

Stanford University Press, 2003.

ASAD, T. Genealogies of religion. Baltimore-London: Johns Hopkins University Press, 1993.

ASSMANN, H.; HINKELAMMERT, F. A idolatria do mercado. Petrópolis: Vozes, 1989.

BENJAMIN, W. O capitalismo como religião. São Paulo: Boitempo, 2013.

BENJAMIN, Walter. Teses sobre o Conceito de História. In: LÖWY, M. Walter

Benjamin: aviso de incêndio. São Paulo: Boitempo. 2005.

BOBINEAU, O.; TANK-STORPER, S. Sociologia das religiões. São Paulo: Loyola, 2011.

COELHO, A. S. Capitalismo como religião: uma crítica a seus fundamentos míticoteológicos. 2014. Tese (Doutorado em Ciências da Religião) - Universidade Metodista de São Paulo, São Bernardo do Campo, 2014.

CROATTO, J. Severino. Os deuses da opressão. In: RICHARD, Pablo et al. A luta dos deuses: os ídolos da opressão e a busca do Deus libertador. São Paulo: Paulinas, 1982. p. 39-66.

DUBUISSON, D. L'Occident et la religion: mythes, science et idéologie. Bruxelles; Paris: Éditions Complexe, 1998.

DUPRONT, A. Qu'est-ce que les Lumières? Paris: Gallimard, 1996.

DUSSEL, E. Por uma ética da libertação latino-americana: uma filosofia da religião antifetichista. São Paulo: Loyola: UNIMEP, 1980a. v. 5 .

FRACHON, A. Le Monde, Paris, edição de 23 de dezembro de 2011.

HERVIEU-LÉGER, D. La religion pour mémoire. 2. ed. Paris: CERF, 2008.

HERVIEU-LÉGER, D. Vers un nouveau christianisme ? Introduction à la sociologie du christianisme occidental. Paris: Cerf, 1986.

HERVIEU-LÉGER, D.; AZRIA, R. (org.) Dictionnaire des faits religieux. Paris: PUF, 2010.

HINKELAMMERT, F. J. As armas ideológicas da morte, São Paulo: Paulinas, 1983. 
HINKELAMMERT, F. J. As raízes econômicas da idolatria: a metafísica do empresário. In: RICHARD, Pablo et al. A luta dos deuses: os ídolos da opressão e a busca do Deus libertador. São Paulo: Paulinas, 1982.

HINKELAMMERT, F. J. Crítica à razão utópica. São Paulo: Paulinas, 1986.

HINKELAMMERT, F. J. Hacia una crítica de la razón mítica: el laberinto de la modernidad. México: Editorial Dríada, 2008.

JOSEPHSON, J. A. The Invention of Religion in Japan. Chicago-London: Chicago University Press, 2012.

LE MONDE, Paris, edição de 17 de janeiro de 2012.

LEBARON, F. Un parfum d'années trente... Savoir/Agir, Bellecombe-en-Bauges, v. 18, janv. 2011.

LÖWY, M. A guerra dos deuses: religião e política na América Latina. Petrópolis:

Vozes/CLACSO, 2000.

LÖWY, M. La guerre des dieux. Paris: Van Dieren, 2019.

LÖWY, M. O Capitalismo como religião: Walter Benjamin e Max Weber. In: JINKINGS, I.; PESCHANSKI (org.). As utopias de Michael Löwy: reflexões sobre um marxista insubordinado. São Paulo: Boitempo, 2007. p. 177-190.

LÖWY, M. O que é cristianismo de libertação. São Paulo: Expressão Popular/ Perseu Abramo, 2016.

LÖWY, M. Walter Benjamin, crítico da civilização. In: BENJAMIN. O capitalismo como religião. S. Paulo: Boitempo, 2013b.

LÖWY, M. Walter Benjamin: aviso de incêndio. São Paulo: Boitempo, 2005.

MASUZAWA, T. The invention of world religions. 5. ed. Chicago: University of Chicago Press, 2012.

MOREIRA, A. S. (org.). O capitalismo como religião. Goiânia: Ed. PUC Goiás, 2012.

MOREIRA, A. S. A religião sob o domínio da estética, Horizonte, Belo Horizonte, v. 13, n. 37, p. 379-405, jan./mar. 2015.

NONGBRI, B. Before Religion: A History of a Modern Concept. New Haven- London: Yale University Press, 2013.

RICHARD, P. et al. A luta dos deuses: os ídolos da opressão e a busca do Deus libertador. São Paulo: Paulinas, 1982.

SUNG, J. M. Desejo, mercado e religião. 2. ed. Petrópolis: Vozes, 1998.

SUNG, J. M. Mercado religioso e mercado como religião. Horizonte, Belo Horizonte, v. 12, n. 34, p. 290-315, abr./jun. 2014. 
SUNG, J. M. Sementes de esperança: a fé cristã em um mundo em crise. Petrópolis:

Vozes, 2005.

SUNG, J. M. Teologia e economia: repensando a teologia da libertação e utopias.

Petrópolis: Vozes, 1994.

TANK-STORPER, Sébastien. Modernité religieuse. In: HERVIEU-LÉGER (org.).

Dictionnaire des faits religieux. Paris: PUF, 2010. p. 742-749.

TSCHANNEN, O. Les théories de la sécularisation. Genève; Paris: Droz, 1992.

WEBER, M. A ciência como vocação. In: WEBER, M. Ciência e política: duas vocações. São Paulo: Martin Claret, 2001b.

WEBER, M. A ética protestante e o espírito do capitalismo. 2. ed. São Paulo: Pioneira Thompson, 2001a.

WILLAIME, J.-P. Sociologie des religions. Paris: PUF, 1995.

WILSON, B. Religion in Sociological Perspective. Oxford: Oxford University Press, 1982.

ZIZEK, S. A permanent economic emergency. New Left Review, n. 64, jul.-ago. 2010. 